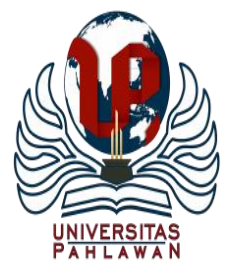

Edukatif : Jurnal Ilmu Pendidikan Volume 3 Nomor 3 Tahun 2021 Halm 738-748

EDUKATIF: JURNAL ILMU PENDIDIKAN

Research \& Learning in Education

https:/ledukatif.org/index.php/edukatif/index

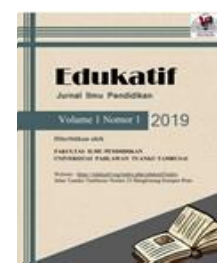

\title{
Pengembangan Kemampuan Representasi Matematis untuk Meningkatkan Number Sense Siswa melalui Soal Berbasis Open Ended
}

\author{
Riyanti Nurdiana ${ }^{1 凶}$, Siti Nur Asmah ${ }^{2}$ \\ Universitas Nahdlatul Ulama Kalimantan Barat, Indonesia ${ }^{1,2}$ \\ E-mail : $\underline{\text { riyantinurdiana03@gmail.com }}^{1}$, $\underline{\text { sitinurasmah1990@gmail.com }}^{2}$
}

\begin{abstract}
Abstrak
Kemampuan representasi matematis siswa masih rendah ditunjukkan dari kesulitan mengerjakan soal TIMSS dengan indikator number relationships (number sense) sehingga perlu dilakukan penelitian yang dapat mengembangkan kemampuan tersebut. Tujuan penelitian adalah mengembangkan kemampuan representasi matematis melalui soal berbasis open ended untuk meningkatkan number sense siswa. Metode yang digunakan dalam penelitian ini adalah penelitian pengembangan (R\&D) model Plomp. Desain pengembangan model Plomp mempunyai 5 fase yaitu: 1) investigasi awal, 2) desain, 3) realisasi/konstruksi, 4) tes, evaluasi dan revisi dan 5) implementasi. Hasil penelitian diperoleh dari setiap tahapan pelaksanaan kegiatan pengembangan soal yang menggunakan model pengembangan Plomp dengan instrumen berupa soal dan wawancara. Hasil penelitian pada 20 siswa di SMA Al Ishlah Pontianak menunjukkan bahwa pengembangan kemampuan representasi matematis melalui dua soal yang layak digunakan berbasis open ended dapat meningkatkan number sense. Hal ini ditunjukkan dari hasil pengerjaan soal yang memperoleh rata-rata 82,5. Siswa menggunakan kemampuan representasi pada saat mengerjakan soal berbasis open ended sehingga indikator number sense muncul daripada mengerjakan soal yang bukan berbasis open ended.
\end{abstract}

Kata Kunci: Kemampuan Representasi Matematis, Number Sense, Soal Berbasis Open Ended.

\begin{abstract}
The ability of students' mathematical representation is still low as indicated by the difficulty in working on TIMSS questions with the number relationships (number sense) indicator so that research is needed to develop this ability. The research objective was to develop mathematical representation skills through openended questions to improve students' number sense. The method used in this research is the Plomp model of development research $(R \& D)$. The Plomp model development design has 5 phases, namely: 1) initial investigation, 2) design, 3) realization / construction, 4) testing, evaluation and revision and 5) implementation. The research results were obtained from each stage of the implementation of question development activities using the Plomp development model with instruments in the form of questions and interviews. The results of research on 20 students at SMA Al Ishlah Pontianak showed that the development of mathematical representation abilities through two questions that were feasible to use based on open ended can improve number sense. This is shown from the results of the problem work which got an average of 82.5. Students use representation skills when working on open ended-based questions so that the number sense indicator appears rather than working on non-open ended questions.
\end{abstract}

Keywords: Mathematical Representation Ability, Number Sense, Open Ended Based Problem.

Copyright (c) 2021 Riyanti Nurdiana, Siti Nur Asmah

$\triangle$ Corresponding author

Email : riyantinurdiana03@gmail.com

DOI : https://doi.org/10.31004/edukatif.v3i3.426

ISSN 2656-8063 (Media Cetak)

ISSN 2656-8071 (Media Online)

Edukatif : Jurnal Ilmu Pendidikan Vol 3 No 3 Tahun 2021 p-ISSN 2656-8063 e-ISSN 2656-8071 


\section{PENDAHULUAN}

Pada umumnya kemampuan siswa dalam mengerjakan soal belum teridentifikasi dengan jelas, guru masih menggunakan penilaian jawaban benar pada soal yang dikerjakan siswa dan tidak memperhatikan indikator kemampuan tertentu yang sudah dicapai siswa salah satunya kemampuan representasi matematis. Pada fase investigasi awal terhadap guru SMA Al Ishlah Pontianak dilakukan wawancara dan observasi, wawancara dengan guru menunjukan bahwa guru memberikan soal deret bilangan dari LKS tanpa memperhatikan bentuk soal dengan indikator kemampuan yang akan dicapai siswa serta tidak menindak lanjuti kesulitan siswa mengerjakan soal. Observasi yang dilakukan ditemukan siswa kesulitan mengerjakan soal TIMSS dengan indikator number relationships (number sense) dan mengerjakan soal deret bilangan dengan cara baku yang diterapkan dari guru dan buku tanpa mengolah kemampuan representasi yang sebenarnya dapat dilakukan untuk menyelesaikan soal.

Representasi adalah salah satu standar proses yang sebaiknya dicapai siswa melalui pembelajaran matematika, namun pelaksanaannya sulit. Hal ini disebabkan keterbatasan pengetahuan guru dan kebiasaan siswa belajar di kelas dengan cara konvensional yang belum memungkinkan untuk menumbuhkan atau mengembangkan daya representasi siswa secara optimal. Hasil penelitian terdahulu menunjukkan bahwa kemampuan representasi matematis masih kurang dikuasai oleh siswa di sekolah. Penelitian (Minggono et al., 2013) menunjukkan bahwa masih kurangnya kemampuan representasi siswa dalam menyelesaikan soal pertidaksamaan pecahan satu variabel bentuk polinom derajat satu, siswa masih cenderung hanya menggunakan representasi simbolik dan jarang sekali yang menggunakan cara grafik maupun garis bilangan. Kemampuan representasi siswa juga dapat dilihat pada saat siswa diberikan tes, hal ini ditunjukkan oleh hasil penelitian (Aryanti et al., 2013) yaitu tes kemampuan representasi matematis pada soal dibuat dengan tujuan untuk mengetahui kecendrungan representasi matematis siswa berdasarkan tingkat kemampuannya.

Menurut (Artiah \& Untarti, 2017) terdapat beberapa kemampuan yang mampu membantu meningkatkan dan mengembangkan siswa dalam berfikir logis, rasional, sistematis, kritis dan kreatif, salah satunya adalah kemampuan representasi matematis. Dari hal tersebut menunjukkan bahwa representasi sangat berperan penting dalam peningkatan kemampuan berpikir untuk pemahaman konsep matematika. (Fitrianna et al., 2018) merumuskan lima indikator kemampuan representasi matematis; 1) menggunakan representasi visual untuk memecahkan masalah; 2) menyajikan data / informasi dari suatu representasi ke dalam diagram, grafik atau tabel dan memecahkan suatu masalah dengan menggunakan kata-kata atau teks tertulis; 3) mengembangkan persamaan atau model matematika dari representasi yang diberikan dan memecahkan masalah dengan melibatkan ekspresi matematika; 4) menggambar pola geometris, menuliskan langkahlangkah pemecahan masalah matematika dengan kata dan memecahkan masalah dengan ekspresi matematika; dan 5) menciptakan situasi masalah berdasarkan data atau representasi yang disediakan.

Representasi juga erat kaitannya dengan open ended, hal ini ditunjukkan dari pernyataan (Fadillah, 2011) yaitu peningkatan kemampuan representasi multipel matematis siswa yang memperoleh pembelajaran dengan pendekatan open ended secara signifikan lebih baik dibandingkan dengan siswa yang memperoleh pembelajaran biasa. Dari pernyataan tersebut bisa ditemukan solusi bahwa dengan pemberian soal berbasis open ended dapat memungkinkan siswa menggunakan kemampuan representasi untuk menyelesaikan masalah pada pengerjaan soal. Menurut (Astin, Anita Ervina; \& Bharata, 2016) untuk meningkatkan kemampuan representasi matematis siswa, diperlukan strategi pembelajaran yang tepat. Salah satunya adalah mengggunakan pendekatan open-ended, pendekatan open-ended adalah pendekatan yang memberikan suatu masalah dengan banyak cara penyelesaian dan banyak jawaban. Respon siswa sangat positif terhadap pembelajaran matematika dengan pendekatan Open-Ended. Pembelajaran matematika dengan pendekatan Open-Ended dapat dijadikan suatu alternatif untuk meningkatkan kemampuan penalaran dan kemampuan representasi siswa (Handri Wijaya, 2016). 
Dalam soal open ended disajikan masalah yang mengandung pemecahan masalah dengan solusi berbagai cara yang beragam. Open ended dapat juga berupa soal dengan satu cara untuk menemukan banyak jawaban yang benar atau soal dengan banyak cara untuk menemukan banyak jawaban yang benar. Belajar matematika dengan mengerjakan soal open ended dapat menantang dan mengakomodasi gaya belajar siswa. Aktivitas dan variasi yang dilakukan untuk menemukan solusi pada soal membantu siswa dalam mengembangkan dan mendemonstrasikan pemahaman matematikanya. Soal open ended dapat diselesaikan dengan ketepatan representasi dan ekskusi artinya jika siswa mengalami kesulitan merepresentasikan masalah matematika maka akan mengalami kesulitan memecahkan masalah pada soal. (Djahuno, 2016) guru menggunakan soal-soal open ended yang telah dibuat pada pokok bahasan barisan dan deret bilangan sebagai alternatif dalam memperkaya variasi pemberian soal matematika untuk melatih berpikir kreatif siswa. Adanya soal open ended siswa bersemangat dan termotivasi untuk membiasakan diri mencari bermacam solusi dari soal open-ended yang diberikan.

Menurut (Setyaningsih \& Ekayanti, 2019) siswa yang memiliki kemampuan number sense tinggi memiliki kepekaan yang baik terhadap bilangan dan operasinya sehingga mampu melihat permasalahan menjadi lebih sederhana dan memilih alternatif penyelesaian lain yang menurutnya lebih mudah tanpa harus mengikuti algoritma baku atau cara procedural. Kemampuan representasi yang ada pada siswa dapat terbentuk dari awal pembelajaran matematika dan ini erat juga kaitannya dengan number sense yang sudah dimiliki. (Maghfirah \& Mahmudi, 2018) menyatakan bahwa siswa yang memiliki kemampuan number sense baik dapat merepresentasikan bilangan dalam berbagai cara tergantung pada masalah yang akan diselesaikan. Kemampuan yang dapat dikembangkan yaitu kemampuan representasi matematis supaya kemampuan number sense yang baik juga dapat terbentuk. Menurut (Authary, 2016) terdapat karakteristik yang memberikan peranan yang sangat penting dalam mengembangkan kemampuan matematika seorang anak. Bagi pendidik untuk mengetahui perkembangan dan karakter dari anak sejak awal, salah satunya adalah kemampuan number sense, number sense anak usia dini yaitu pada komponen pemahaman makna bilangan menggunakan representasi benda konkrit sebagai pengganti dari bilangan tertentu. Dari pernyataan tersebut dapat dinyatakan bahwa kemampuan representasi dapat mengembangkan number sense karena number sense itu sendiri merupakan pemahaman terhadap bilangan dengan cara yang fleksibel dan terbuka menggunakan berbagai cara atau representasi untuk solusi penyelesaian masalah.

Dari paparan diatas maka dilakukan penelitian yang bertujuan mengembangkan kemampuan representasi matematis melalui soal open ended untuk meningkatkan number sense siswa. Penelitian ini berbeda dari penelitian sebelumnya karena dilakukan untuk mengetahui kemampuan awal representasi matematis dan number sense siswa serta menghasilkan soal berbasis open ended yang layak digunakan untuk mengidentifikasi kedua hal tersebut. Penelitian terdahulu (Bagus, 2018) hanya menganalisis kemampuan representasi matematis siswa dalam menyelesaikan soal, kemampuan representasi matematis sangat penting dan dibutuhkan oleh siswa dalam memahami materi yang diberikan dan menyelesaikan soal, jika kemampuan representasi matematis kurang maka menyebabkan kurangnya pemahaman siswa dalam materi yang diberikan sehingga siswa susah memahami dan mengerjakan soal yang disediakan. Pada penelitian (Mucti \& Nurmala, 2020) menyatakan salah satu hal yang mempengaruhi hasil belajar matematika siswa adalah kemampuan number sense, semakin besar tingkat kemampuan number sense siswa maka berdampak positif terhadap hasil belajar matematika siswa. Saat ini belum ada penelitian yang mengembangkan kemampuan representasi untuk meningkatkan number sense yang sebaiknya dilakukan supaya tingkat pemahaman siswa terhadap matematika meningkat dan siswa dapat menyelesaikan soal-soal yang tidak rutin seperti open ended. Peneliti berharap dengan adanya soal ini juga dapat membantu guru mengidentifikasi kemampuan representasi matematis dan number sense siswa serta membiasakan siswa berhadapan dengan soal open ended dan menggunakan kemampuan tersebut untuk memecahkan masalah pada pembelajaran matematika. 
741 Pengembangan Kemampuan Representasi untuk Meningkatkan Number Sense Siswa melalui Soal Berbasis Open Ended-Riyanti Nurdiana,Siti Nur Asmah

DOI: https://doi.org/10.31004/edukatif.v3i3.426

\section{METODE PENELITIAN}

Metode yang digunakan dalam penelitian ini adalah penelitian pengembangan (R\&D) model Plomp. Desain pengembangan model Plomp (Rochmad, 2012) mempunyai 5 fase dalam tahap pelaksanaannya. Fasefase model Plomp yaitu: (1) fase investigasi awal (preliminary investigation), (2) fase desain (design), (3) fase realisasi/konstruksi (realization/construction), (4) fase tes, evaluasi dan revisi (test, evaluation and revision) dan (5) fase implementasi (implementation).

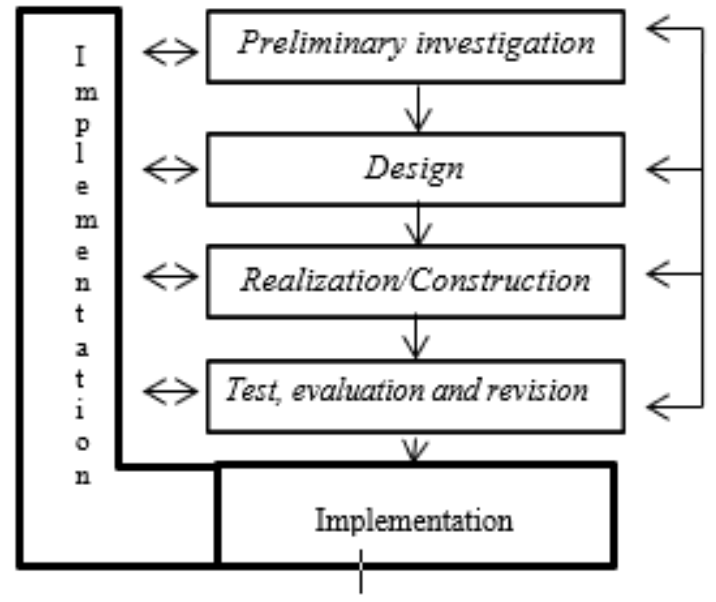

\section{Gambar 1. Tahapan Penelitian}

Subjek uji coba terbatas dalam penelitian ini adalah siswa kelas XI SMA Bina Utama Pontianak dan siswa kelas XI SMA Tunas Bakti Pontianak. Subjek penelitian uji coba lapangan dalam penelitian ini adalah siswa kelas XI SMA Al Ishlah Pontianak. Peneliti mengambil subjek penelitian kelas XI karena siswa sudah mempelajari materi deret bilangan. Prosedur dalam penelitian ini terdiri dari 5 fase sebagai berikut. (1) Fase investigasi awal yaitu tahap awal melakukan kajian dan analisa terhadap hal-hal yang diperlukan sebelum tes dikembangkan. Hal-hal yang dapat dilakukan antara lain analisis materi, analisis kebutuhan guru dan analisis siswa. (2) Fase desain, setelah proses analisis pada fase investigasi awal selesai, maka selanjutnya adalah fase desain yang merupakan tahapan merancang soal-soal berbasis open ended berdasarkan indikator kemampuan representasi matematis dan number sense. Prosedur dalam merancang soal yaitu memperhatikan karakter soal berbasis open ended, menentukan indikator kemampuan representasi matematis dan number sense, menentukan jenis soal, menyususun kisi-kisi, menulis soal, membuat alternatif jawaban dan pedoman penskoran. (3) Fase realisasi / konstruksi, fase ini dilakukan dengan membuat soal yang telah disusun berdasarkan kriteria pada fase desain sehingga terbentuk soal berbasis open ended yang memuat indikator kemampuan number sense dan alternatif jawaban beserta pedoman penskoran. Pada fase ini instrumen soal dinamakan prototipe 1. (4) Fase tes, evaluasi dan revisi, pada tahapan ini dilakukan 2 kegiatan utama yaitu: kegiatan validasi, sebelum kegiatan validasi soal dilakukan, terlebih dahulu dikembangkan instrumen untuk memvalidasi. Jenis instrumen yang digunakan dalam fase ini adalah lembar validasi. Instrumen sebelum digunakan, terlebih dahulu uji coba terbatas skala kecil (uji coba 1) kepada 5 siswa SMA Bina Utama Pontianak, hasilnya di analisis dan direvisi soal yang tidak dapat digunakan, hasil revisi menghasilkan prototipe 2 kemudian divalidasi oleh para ahli untuk menguji valid atau tidaknya instrumen yang akan digunakan untuk mengukur aspek-aspek yang ditetapkan, ditinjau dari kejelasan tujuan pengukuran yang dirumuskan kesesuaian butir-butir pertanyaan untuk setiap aspek, penggunaan bahasa, dan kejelasan petunjuk penggunaan instrumen. Kegiatan validasi isi soal dilakukan dengan memberikan instrumen validasi pada para ahli yang menggunakan skala likert (Kurniawati, 2021). Para ahli yang bertindak sebagai validator adalah dosen dan guru. Saran dari validator digunakan sebagai landasan penyempurnaan atau revisi soal, kegiatan uji coba, setelah di revisi dan di validasi oleh validator dihasilkan prototipe 3, kemudian uji coba terbatas skala besar (uji coba 2) dilakukan untuk menentukan kelayakan soal melalui uji validasi dengan rumus berikut. 


$$
A P=\frac{\text { Skor Aktual }}{\text { Skor ideal }} \times 100 \%
$$

Tabel 1. Kategori Uji Validasi

\begin{tabular}{ll}
\hline Interval & Kategori \\
\hline $81-100 \%$ & Sangat tinggi \\
$61-80 \%$ & Tinggi \\
$41-60 \%$ & Cukup \\
$21-40 \%$ & Rendah \\
$1-20 \%$ & Sangat rendah \\
\hline
\end{tabular}

Hasil uji validasi soal berbasis open ended untuk mengembangkan kemampuan representasi matematis yang meningkatkan number sense siswa dapat dinyatakan layak untuk diuji coba bila persentase minimal mencapai kategori tinggi yakni $\geq 61 \%$ (Prabandari \& Kristin, 2021).

Setelah di analisis jika memenuhi kriteria tes yang layak maka dihasilkan prototipe final dan bisa diimplementasikan. (5) Fase Implementasi, setelah dilalui setiap fase pada prosedur pengembangan tes, mulai dari tahap investigasi awal sampai tahap tes, evaluasi dan revisi pada seluruh komponen-komponen instrumen penelitian. Jika terdapat perbaikan (revisi) atau perubahan maka segera dilakukan peninjauan pada bagianbagian instrumen penelitian. Selanjutnya diimplementasikan atau uji coba lapangan kepada subjek penelitian. Hasil uji coba tes di analisis untuk diketahui seberapa besar kemampuan representasi matematis dan peningkatan number sense dilihat dari skor pengerjaan soal pada siswa secara keseluruhan kemudian dikategorikan dan dilakukan wawancara terhadap siswa untuk mengetahui lebih mendalam kemampuan representasi dan number sense siswa. Berikut tabel kategori skor hasil pengerjaan soal.

Tabel 2. Kategori Hasil Belajar Siswa

\begin{tabular}{lll} 
Rata-rata Nilai & Nilai & Kategori \\
\hline 80 ke atas & A & Baik Sekali \\
$66-79$ & B & Baik \\
$60-65$ & C & Cukup \\
$46-59$ & D & Kurang \\
45 ke bawah & E & Gagal \\
\hline
\end{tabular}

\section{HASIL DAN PEMBAHASAN}

Hasil penelitian tentang pengembangan kemampuan representasi matematis untuk meningkatkan number sense siswa melalui soal berbasis open ended melalui 5 tahapan penelitian, berikut penjelasan tahaptahapnya. 1) Fase investigasi awal, dilakukan tiga kegiatan analisis yaitu (a) analisis materi, melakukan kegiatan mengidentifikasi konsep-konsep utama yang akan digunakan dalam soal pada materi kelas XI. Berdasarkan kegiatan analisis materi, didapatkan bahwa materi yang digunakan dalam pengembangan soal berbasis open ended yang dapat memuat indikator kemampuan representasi matematis dan number sense adalah materi kurikulum 2013 mata pelajaran matematika kelas XI semester genap deret bilangan (b) analisis kebutuhan guru untuk mengetahui kebutuhan guru terhadap soal-soal dilakukan wawancara dengan guru matematika yang mengajar di SMA Al Ishlah Pontianak, hasil analisis kebutuhan guru menunjukkan soal-soal yang digunakan oleh guru hanya berupa soal dengan pemecahan masalah sederhana yang sesuai dengan 
743 Pengembangan Kemampuan Representasi untuk Meningkatkan Number Sense Siswa melalui Soal Berbasis Open Ended-Riyanti Nurdiana,Siti Nur Asmah

DOI: https://doi.org/10.31004/edukatif.v3i3.426

contoh yang guru berikan sebelumnya; (c) analisis siswa dengan melakukan telaah karakteristik siswa meliputi kemampuan representasi matematis dan number sense siswa dalam mengerjakan soal dengan diberikan beberapa tes pada studi pendahuluan. Dari hasil studi pendahuluan dapat disimpulkan bahwa kemampuan number sense siswa tergolong rendah karena dari 20 siswa hanya 3 yang dapat menyelesaikan kedua soal number sense dengan benar. 2) Pada fase kedua (desain), mendesain perangkat soal yang terdiri dari kisi-kisi, butir soal, alternatif jawaban dan pedoman penskoran. 3) Fase ketiga (realisasi), hasil pengembangan instrument soal disajikan berdasarkan rancangan pada fase desain disebut prototipe 1 .

\section{SOAL DERET MATEMATIKA KELAS XI BERBASIS OPEN ENDED (PROTOTIPE 1)}

1. Ada 50 bola yang akan di masukkan ke dalam keranjang, tiap-tiap keranjang berisi sejumlah bola yang berbeda. Agar jumlah bola pada tiap-tiap keranjang membentuk deret aritmatika. berapakah iumlah bola terbanyak yang dapat diletakkan pada salah satu keranjang?

2. Didalam ruang pertunjukkan terdapat 8 baris kursi, baris paling depan terdapat 5 kursi, baris berikutnya 3 kursi lebih banyak dari baris di depannya. Jumlah kursi dalam ruangan tersebut adalah....

\section{Gambar 2. Prototipe 1}

4) Fase keempat (tes, evaluasi dan revisi), soal tes diujicobakan, direvisi menghasilkan prototipe 2 kemudian divalidasi oleh 3 ahli yang merupakan guru dan dosen dibidang kependidikan dan diuji cobakan kembali menghasilkan prototipe 3 yang memiliki kualitas tes yang memenuhi aspek kelayakan.

\section{SOAL DERET MATEMATIKA KELAS XI BERBASIS OPEN ENDED (PROTOTIPE 2)}

1. Ada 50 bola yang akan dimasukkan ke keranjang setiap keranjang berisi sejumlah bola yang berbeda Agar jumlah bola pada tiap keranjang membentuk deret aritmatika, berapakah jumlah bola terbanvak yang dapat diletakkan pada satu keranjang?

2. Di dalam ruang pertunjukkan terdapat 8 baris kursi. Baris paling depan terdapat 5 kursi, baris berikutnva 3 kursi lebih banyak dari baris di depannva. Berapa jumlah kursi dari baris 1 hingga baris ke 4 dalam ruangan tersebut?

\section{Gambar 3. Prototipe 2}


744 Pengembangan Kemampuan Representasi untuk Meningkatkan Number Sense Siswa melalui Soal Berbasis Open Ended-Riyanti Nurdiana,Siti Nur Asmah

DOI: https://doi.org/10.31004/edukatif.v3i3.426

Tabel 3. Hasil Uji Tingkat Validitas

\begin{tabular}{llccc}
\hline Validator & Skor Ideal & Skor Aktual & Persentase & Kategori \\
\hline Guru Matematika & 140 & 120 & $85,71 \%$ & Tinggi \\
Dosen Matematika & 125 & 90 & $72 \%$ & Tinggi \\
Dosen Bahasa Indonesia & 140 & 100 & $71,42 \%$ & Tinggi
\end{tabular}

Hasil uji tingkat validitas menurut guru diperoleh persentase $85,71 \%$ kategori tinggi. Validasi oleh guru Matematika meliputi aspek kelayakan isi sesuai jenjang pendidikan, kesesuaian dengan materi dan penyajian bentuk soal. Hasil uji tingkat validitas menurut dosen Pendidikan Matematika diperoleh persentase $72 \%$ kategori tinggi. Validasi oleh dosen pertama meliputi aspek keterkaitan dengan open ended, indikator kemampuan representasi matematis dan indikator number sense, keterpaduan, penekanan dan kejelasan materi. Hasil uji tingkat validitas menurut dosen Pendidikan Bahasa Indonesia diperoleh persentase 71,42\%. Validasi oleh dosen kedua meliputi aspek ejaan bahasa yang baik, keterkaitan kalimat pada soal, tidak memiliki makna ganda. Dari ketiga ahli validasi menunjukkan bahwa hasil uji validasi dapat dinyatakan layak untuk diuji coba setelah di revisi berdasarkan saran validator karena persentase minimal mencapai kategori tinggi yakni $\geq 61 \%$.

5) Fase kelima (implementasi). Pada bagian ini prototipe 3 menghasilkan prototipe final yang diimplementasikan pada subjek penelitian yaitu kelas XI di SMA Al Ishlah Pontianak berjumlah 20 siswa. Pengerjaan soal memuat indikator kemampuan representasi matematis yaitu: a) menggunakan representasi untuk memodelkan dan menafsirkan masalah matematika secara fisik; b) membuat dan menggunakan representasi untuk mengatur, merekam dan mengkomunikasikan ide-ide matematika; memilih, menerapkan dan c) menterjemahkan suatu representasi matematika untuk menyelesaikan masalah matematika. Indikator number sense yang juga terdapat pada tahap pengerjaan soal yaitu: a) kepekaan memilih metode efisien dari berbagai representasi yang dapat digunakan; b) prosedur yang digunakan berkaitan dengan penggunaan sifat operasi bilangan; c) prosedur yang digunakan fleksibel, tidak hanya mengikuti cara pada umumnya atau yang diajarkan oleh guru.

SOAL DERET MATEMATIKA KELAS XI BERBASIS OPEN ENDED (PROTOTIPE 3)

1. Ada 60 bola yang akan dimasukkan ke 5 keranjang setiap keranjang berisi sejumlah bola yang berbeda Agar jumlah bola pada tian keranjang membentuk deret aritmatika berapakah jumlah bola terbanvak yang dapat diletakkan pada satu keranjiang?

2. Di dalam ruang pertunjukkan terdapat 6 baris kursi yang membentuk deret aritmatika. Kursi pada baris paling depan ada 5 kursi dan kursi pada baris ke 6 beriumlah 20. Berapakah jumlah kursi dari barisan ke 2 sampai ke 5 dalam raangan tersebut?

\section{Gambar 4. Prototipe 3}


745 Pengembangan Kemampuan Representasi untuk Meningkatkan Number Sense Siswa melalui Soal Berbasis Open Ended-Riyanti Nurdiana,Siti Nur Asmah

DOI: https://doi.org/10.31004/edukatif.v3i3.426

Hasil pengembangan kemampuan representasi matematis dengan menggunakan soal yang dikembangkan memperoleh nilai rata-rata 82,5. Hal ini menunjukkan bahwa hasil pengembangan kemampuan siswa dengan menggunakan soal berbasis open ended berkategori baik sekali karena nilai rata-rata diatas 80 (Sudijono, 2011). Hasil dari pengembangan kemampuan representasi matematis melalui soal berbasis open ended untuk meningkatkan number sense siswa dengan melihat gambaran pengerjaan soal dari siswa dan skor nilai sebagai berikut.

\section{Jawaban Siswa}
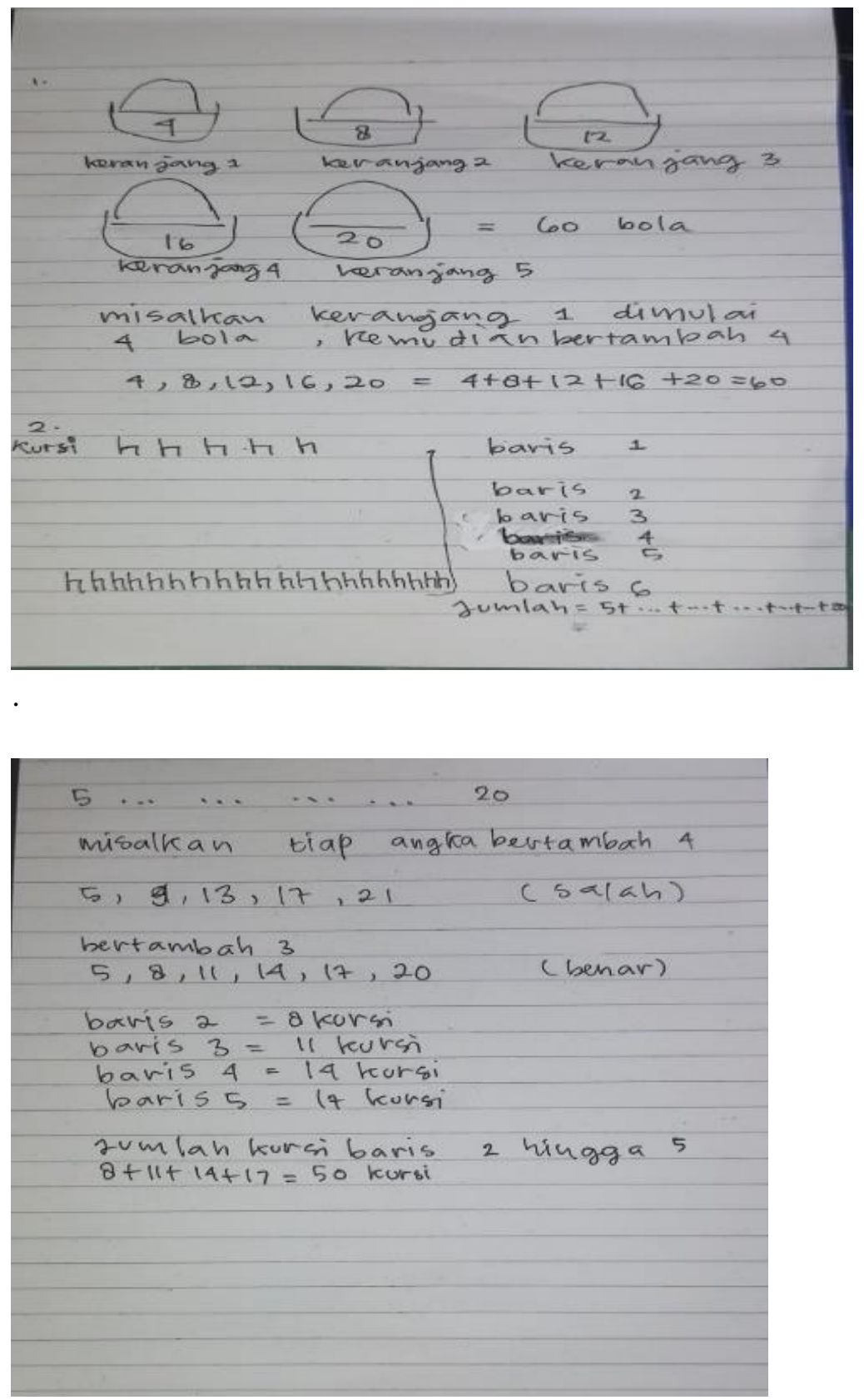

\section{Deskripsi Kemampuan Representasi}

Matematis dan Number Sense

Pada soal no 1 dan 2 terlihat kemampuan representasi siswa yaitu siswa menggambar ilustrasi keranjang dan kursi kemudian menghitung menggunakan perkiraan. Kemampuan number sense terlihat pada cara yang digunakan fleksibel dan tidak menggunakan rumus matematika yang diajarkan pada materi deret aritmatika.

Indikator yang telah dicapai siswa untuk pengembangan kemampuan representasinya yaitu menggunakan representasi untuk menafsirkan masalah matematika dari soal, membuat dan menggunakan representasi, menerapkan dan menterjemahkan suatu representasi matematika untuk menyelesaikan masalah matematika.

Indikator yang telah dicapai siswa untuk peningkatan number sense yaitu memahami dunia matematika yang dinyatakan dengan simbol numerik, menciptakan prosedur sesuai dengan caranya sendiri, merepresentasikan bilangan dalam berbagai cara, mengidentifikasi pola bilangan, memeriksa perhitungan numerik dan memahami sifatsfiat umum dari suatu permasalahn numerik tanpa melakukan perhitungan yang baku.

\section{Gambar 5. Jawaban Siswa}


DOI: https://doi.org/10.31004/edukatif.v3i3.426

\section{Tabel 4. Tes Kemampuan Siswa dengan Menggunakan Soal yang Dikembangkan}

\begin{tabular}{lcl}
\hline Nilai Akhir & Jumlah Siswa & Kategori \\
\hline 80 keatas & 16 & Baik sekali \\
$66-79$ & 4 & Baik \\
$60-65$ & 0 & Cukup \\
$46-59$ & 0 & Kurang \\
45 kebawah & 0 & Gagal \\
Jumlah & 20 & \\
\hline
\end{tabular}

Hasil wawancara setelah siswa mengerjakan soal berbasis open ended menjelaskan bahwa siswa merasa tertantang mengerjakan soal dan berpikir untuk mencari penyelesaian tanpa menggunakan rumus karena peneliti sudah menerangkan bahwa untuk mengerjakan soal bisa dengan menggunakan cara apapun. Siswa menyatakan bahwa guru biasanya memberikan soal yang mirip dengan contoh dan menerangkan rumus yang digunakan seperti dibuku. Siswa merasa bahwa pembelajaran terlalu kaku dan tidak memberi kesempatan untuk siswa mencoba berbagai representasi matematis.

Hasil penelitian mendeskripsikan bahwa dari 20 siswa, 16 siswa memenuhi indikator kemampuan representasi siswa dalam mengerjakan soal open ended dan menjawab hampir benar. Siswa menggunakan berbagai representasi seperti mengubah soal dalam bentuk lain seperti gambar, numerik, simbol, verbal kemudian menghitungnya secara lisan, dan ada yang menyelesaikan dengan penalaran. Hal ini dipicu karena pemahaman siswa tentang berbagai representasi muncul ketika diberikan soal non rutin seperti open ended sesuai dengan penelitian yang dilakukan oleh (Fadillah, 2011) bahwa siswa yang memperoleh pembelajaran dengan pendekatan open ended menunjukkan peningkatan kemampuan representasi multipel matematis yang lebih tinggi daripada siswa yang memperoleh pembelajaran biasa. Untuk 4 siswa tidak menjawab dan ada yang menjawab dengan representasi yang tidak menuju penyelesaian masalah. Kesulitan siswa disebabkan karena kurangnya pengetahuan tentang representasi yang sesuai untuk digunakan dalam menyelesaikan masalah dalam matematika. Selain itu, sebagian besar siswa mengalami kesulitan dalam memahami soal open ended. Siswa jarang dan bahkan tidak pernah mengerjakan soal seperti yang tersajikan. Hal ini sejalan dengan hasil penelitian (Mursidik et al., 2014) yang menyatakan siswa dalam menggunakan cara dalam menyelesaikan masalah pada umumnya menggunakan cara yang biasa digunakan dan tidak mengarah mengarah pada penyelesaian. Siswa hanya mampu memunculkan satu ide dalam menyelesaikan masalah matematika open-ended sehingga siswa mengalami kesulitan. Dengan adanya penelitian ini memberikan motivasi bagi guru untuk lebih kreatif menciptakan soal-soal yang dapat memunculkan kemampuan peserta didik dan meningkatkan hasil belajar. Keterbatasan temuan penelitian ini hanya difokuskan pada soal open ended materi deret bilangan sehingga yang dapat dijadikan acuan penelitian selanjutnya adalah indikator kemampuan peserta didik lainnya yang bisa dikembangkan melalui berbagai tipe soal matematika.

\section{KESIMPULAN}

Berdasarkan hasil penelitian dan pembahasan disimpulkan bahwa: 1) pengembangan kemampuan representasi matematis untuk meningkatkan number sense siswa melalui soal berbasis open ended melalui 5 tahapan yaitu a) investigasi awal dengan melakukan analisis terhadap guru dan siswa yang dilakukan dengan wawancara; b) desain dengan merancang soal sesuai dengan analisis yang telah dilakukan pada tahap awal; c) realisasi dengan membuat soal yang telah dirancang, d) tes, evaluasi dan revisi dengan melakukan uji coba terbatas kepada dua sekolah, mengevaluasi soal dengan meminta saran dari validator kemudian merevisi soal sesuai dengan saran yang diberikan, meminta validator menguji kelayakan soal sebelum diuji cobakan lagi 
747 Pengembangan Kemampuan Representasi untuk Meningkatkan Number Sense Siswa melalui Soal Berbasis Open Ended-Riyanti Nurdiana,Siti Nur Asmah

DOI: https://doi.org/10.31004/edukatif.v3i3.426

sekolah lain ; e) implementasi, memberikan soal kepada siswa (subjek penelitian) kemudian melihat hasil untuk diidentifikasi adanya pengembangan kemampuan representasi dan peningkatan number sense setelah diberikan soal berbasis open ended. 2) kelayakan soal termasuk kategori tinggi dengan rata-rata 85,71\%. 3, rata-rata hasil belajar siswa mengerjakan soal berbasis open ended yaitu 82,5 menunjukkan terdapat pengembangan kemampuan representasi matematis untuk meningkatkan number sense siswa.

\section{DAFTAR PUSTAKA}

Artiah, \& Untarti, R. (2017). Pengaruh Model Reciprocal Teaching Terhadap Kemampuan Representasi Matematis Siswa Kelas VII SMP Negeri 6 Purwokerto. AlphaMath, 3(1), 1-11.

Aryanti, D., Zubaidah, \& Nursangaji, A. (2013). Kemampuan Representasi Matematis menurut Tingkat Kemampuan Siswa pada Materi Segi Empat. Jurnal Pendidikan Dan Pembelajaran, 2(1).

Astin, Anita Ervina; \& Bharata, H. (2016). Penerapan Pendekatan Open Ended dalam Pembelajaran Matematika Terhadap Kemampuan Representasi Matematis Siswa. Prosiding Konferensi Nasional Penelitian Matematika dan Pembelajarannya (KNPMP) I, 20, 631-639.

Authary, N. (2016). Number Sense Anak Usia Dini: Suatu Investigasi pada Aritmatika Tahap Awal. Bunayya, I(2), 1-15.

Bagus, C. (2018). Analisis Kemampuan Representasi Matematis Siswa Dalam Menyelesaikan Soal Lingkaran Pada Kelas VII-B Mts Assyafi'iyah Gondang. Suska Journal of Mathematics Education, 4(2), 115. https://doi.org/10.24014/sjme.v4i2.5234

Djahuno, S. (2016). Pengembangan soal-soal open-ended pada pokok bahasan barisan dan deret bilangan di kelas IX a SMP Negeri 2 Tolitoli. Jurnal Kreatif Tadulako Online, 4(6), 272-281. http://jurnal.untad.ac.id/jurnal/index.php/JKTO/article/view/6139

Fadillah, S. (2011). Meningkatkan Kemampuan Representasi Multipel Matematik, Pemecahan Masalah Matematik dan Self Esteem siswa SMP melalui Pembelajaran dengan Pendekatan Open Ended. Jurnal Pendidikan Matematika, 2(2).

Fitrianna, A. Y., Dinia, S., Mayasari, M., \& Nurhafifah, A. Y. (2018). Mathematical Representation Ability of Senior High School Students: An Evaluation from Students' Mathematical Disposition. JRAMathEdu (Journal of Research and Advances in Mathematics Education), 3(1), 46. https://doi.org/10.23917/jramathedu.v3i1.5872

Handri Wijaya. (2016). Peningkatan Kemampuan Penalaran dan Representasi Siswa melalui Pembelajaran Pendekatan Open Ended. Didaktik: Jurnal Pendidikan Guru Sekolah Dasar, 152(3), 28.

Kurniawati, D. \& M. (2021). Pengembangan Instrumen Penilaian Sikap Gotong Royong dalam Pembelajaran Tematik di Sekolah Dasar. Edukatif : Jurnal Ilmu Pendidikan, 3(3), 640-648.

Maghfirah, M., \& Mahmudi, A. (2018). Number Sense: The Result of Mathematical Experience. Journal of Physics: Conference Series, 1097(1). https://doi.org/10.1088/17426596/1097/1/012141

Minggono, S., Sugianto, \& Jamiah, Y. (2013). Kemampuan Representasi Matematis Siswa dalam Pertidaksamaan Pecahan di kelas X SMA. Pendidikan dan Pembelajaran, 2(3), 1-10.

Mucti, A., \& Nurmala, R. (2020). Pengaruh Kemampuan Number Sense Terhadap Hasil Belajar 
748 Pengembangan Kemampuan Representasi untuk Meningkatkan Number Sense Siswa melalui Soal Berbasis Open Ended-Riyanti Nurdiana,Siti Nur Asmah

DOI: https://doi.org/10.31004/edukatif.v3i3.426

Matematika Siswa Di SMP Negeri 8 Tarakan Universitas Borneo Tarakan Matematika memiliki beberapa arti , diantaranya adalah ( Abdurrahman , 2009 ): ( 1 ) Sebagai ilmu pengatahuan yang terorganisir seca. MUST: Journal of Mathematics Education, Science and Technology, 5(1), 1218.

Mursidik, E. M., Samsiah, N., \& Rudyanto, H. E. (2014). Analisis Kemampuan Berpikir Kreatif Siswa SD dalam Memecahkan Masalah Matematika. LPPM Vol. 2 No.1, 8-9.

Prabandari, A. S., \& Kristin, F. (2021). Pengembangan LKS IPS Berbasis Creative Problem Solving untuk Meningkatkan Kemampuan Berpikir Kreatif Siswa di Sekolah Dasar Abstrak. Edukatif: Jurnal Ilmu Pendidikan, 3(2), 355-363.

Rochmad. (2012). Desain Model Pengembangan Perangkat Pembelajaran Matematika. Kreano: Jurnal Matematika Kreatif-Inovatif, 3(1), 59-72. https://doi.org/10.15294/kreano.v3i1.2613

Setyaningsih, L., \& Ekayanti, A. (2019). Keterampilan Berfikir Siswa SMP dalam Menyelesaikan Soal Matematika Ditinjau dari Kemampuan Number Sense. Jurnal Didaktik Matematika, 6(1), 29-40. https://doi.org/10.24815/jdm.v6i1.11699 